\title{
NEW NORTH AMERICAN PARASITIC COPEPODS, NEW HOSTS, AND NOTES ON COPEPOD NOMENCLATURE.
}

\author{
By Charles Branch Wilson,
}

Department of Biology, State Normal School, Westfield, Massachusetts.

\section{INTRODUCTION.}

This is the seventeenth paper in the series dealing with the parasitic copepods in the collection of the United States National $\mathrm{Mu}$ seum. ${ }^{1}$ It is chiefly concerned with two collections recently received by the author. One of these was from Dr. H. M. Smith, former Commissioner of Fisheries, and included specimens collected by him at Woods Hole during the summer of 1922 . The other was from Dr. Edwin Linton, the able parasitologist, and was made up of specimens collected at Woods Hole during the past 15 years. To both of these investigators sincere thanks are returned for the material thus placed at the author's disposal.

To these collections have been added specimens sent for identification, and a few others belonging to the original lot sent from the United States National Museum. Together these constitute an important addition to the valuable Museum series, in which they appear under the numbers here recorded. They include a new genus, several new species, and many new hosts.

\footnotetext{
1 The sixteen preceding papers, all of which were published in the Proceedings of the United States National Museum, are: 1. The Argulidae, vol. 25, pp. 635-742, pls. 8-27. 2. Descriptions of Argulidae, vol. 27, pp. 627-655, 38 text figures. 3. The Caliginae, vol. 28, pp. 479-672, pls. $5-29$. 4. The Trebinae and Euryphorinae, vol. 31, pp. 669-720, pls. 15-20. 5. Additional Notes on the Argulidae, vol. 32, pp. 411-424, pls. 29-32. 6. The Pandarinae and Cecropinae, vol. 33, pp. 323-490, pls. 17-43. 7. New Species of Caliginae, vol. 33, pp. 593-627, pls. 49-56. 8. Parasitic Copepods from Pacific Coast, vol. 35, pp. 431-481, pls. 66-83. 9. Development of Achtheres ambloplitis Kellicott, vol. 39, pp. 189-226, pls. 29-36. 10. The Ergasilidae, vol. 39, pp. 263-400, pls. 41-60. 11. Descriptions of new genera and species, vol. 39 , pp. 625-634, pls. 65-68. 12. Descriptions of new species, vol. 42, pp. 233-243, pls. 30-34. 13. The Lernaeopodidae, vol. 47, pp. 565-729, pls. 25-56. 14. The Lernaeidae, vol. 53, pp. 1-150, pls. 1-21. 15. The Sphyriidae, vol. 55, pp. 549-604, pls. 50-59. 16. The Dichelesthiidae, vol. 60, Art. 5, pp. 1-100, pls 1-13.
}

No. 2507.-Proceedings U. S. National Museum, Vol. 64, Art. 17. 


\section{NEW SPECIES AND A NEW GENUS.}

\section{ARGULUS NOBILIS, Thiele.}

Plate 1, figs. 6-9.

Argulus nobilis Thiele, Mittheilungen aus dem Zoologischen Museum zu

Berlin, vol. 2, Heft 4, p. 28, pl. 7, figs. 64-66 ; pl. 8, figs. 67-76, 1904.

Argulus ingens Wrlson, Proceedings U. S. National Museum, vol. 42, 1912, p. 233 , pl. 30 , figs. $1-6$; pl. 31 , fig. 7 .

Host and record of specimens.-The New York aquarium secured from Lake Calcasieu, Louisiana, about two years ago a colony of alligator gars, Lepisosteus tristoechus, and kept them on exhibition for a long time. They became so badly infested with the above species of Argulus that it was necessary to take the fish out of their aquarium and remove the parasites. The latter were preserved and sent to the author for identification; they included adults of both sexes and various developmental stages. The amount of material was sufficient to make possible the identity of the two species indicated above.

Thiele had but seven specimens, including a single male, when the species was originally described, while the present author had one male and two females upon which to found the species ingens. Between the species as described and figured there were substantial differences. But the large number of specimens in the present material, and especially the developmental stages, forms a series that passes into nobilis on the one hand, and into ingens on the other. We are forced to conclude therefore that the two forms are simple variations of one and the same species, and if so, Thiele's name takes precedence. Such a conclusion was suggested by the present author in $1916,{ }^{2}$ but at that time there was no basis of actual proof. The two descriptions with their accompanying figures may be accepted as published, each for its own variety. The one presented by Thiele may then be known as Argulus nobilis, variety nobilis, and the one by the present author as Argulus nobilis, variety ingens.

In the present paper developmental stages are described and figured for the first time.

Color.-Thiele stated that his specimens were faintly tinged with brown, but when alive were probably transparent. The color of ingens (preserved material) was given as a uniform yellowish-brown. The present material shows a few specimens that are almost transparent, others that are yellowish-brown, and still others that are dark cinnamon-brown. The general impression of a hundred specimens spread out dorsal side uppermost is a dark shade of brown.

2 Bulletin, Bureau of Fisheries, vol. 34, p. 354. 
Young male.-The dorsal view of a male about $4 \mathrm{~mm}$. long is shown in Figure 6 and attention is called to many differences between this form and the adult. The carapace is fully a fourth longer than wide, and it only reaches the anterior margin of the third legs instead of overlapping the abdomen: the posterior sinus is short and fully as wide as long. The arrangement of the chitin ribs on the dorsal surface of the head is more distinct than in mature specimens, and is different from that shown in any of the published figures. The chitin ribs are strongly curved between the lateral eyes, and each is forked just behind the median eye, posterior to which the two are nearly parallel. The inner branch of the fork curves backward and inward and meets its fellow from the other side on the midline, forming a reentrant notch. The outer branch curves backward and outward and nearly or quite meets the lateral groove.

Behind the posterior end of this lateral groove, and extending forward a short distance on either side, is a narrow fold of skin. From either end of this skin fold a groove extends backwards and inwards to the corresponding corner of the base of the posterior sinus.

The abdomen is nearly one-third of the entire length, and is also one-half longer than wide. It is widest at the center instead of at the anterior end and shows but the faintest indication of the fingerlike processes that later appear at the anterior corners. The testes are half in front and half behind the longitudinal center, whereas later they are wholly in front of the center. The posterior sinus is less than a fourth of the abdomen's length; the anal laminae are lateral, but much nearer the distal than the proximal end of the sinus; the posterior lobes are broad and bluntly rounded.

The swimming legs are like those of the adult except that they are relatively longer and more slender. The boot-like lobes at the base of the posterior pair are also longer and narrower. Such great differences are suggestive of another species, but the appendages and mouth-parts are exactly like those of the adult, and all the intermediate stages are present to show just how the transformation progresses.

Young female.-The young female differs from the adult in much the same particulars as the male. The abdomen of one only $4 \mathrm{~mm}$. in length is seen in Figure 7, and it may be noted that it corresponds exactly with that of the young male. Two or three details stand out much more clearly than in the adult. The first of these is the peculiar form of the basal plate of the maxillipeds shown in Figure 8. Neither Thiele's figure (pl. 8, fig. 68) nor that of the present author ${ }^{3}$ show the sharp bend in this plate just above the raised area.

${ }^{8}$ Proc. U. S. Nat. Mus., vol. 42, 1912, pl. 30, fig. 3. 
The two outer teeth of this plate are so close together and so far removed from the inner one that it seems as if there must have been originally a single tooth at each corner of the plate, and that the outer one subsequently divided.

The second feature is easily overlooked in the adult and has not been noted hitherto. On the endopods of the third and fourth legs in both sexes, at the distal end of the basal joint and on the anterior margin is a finger process extending obliquely outwards. These processes in the male are larger than in the female, and in both sexes those on the fourth legs are longer than those on the third legs.

A third feature is the boot-shaped lamella at the base of the fourth legs in the female. These are larger than those of the male and have a pronounced heel (fig. 9).

Remarks.-It is well that these two very large argulids should be thus identified, but the very fact that an exceptional abundance of material has led to this result suggests that other closely related species might share the same fate if they could be bred in sufficient numbers. The larger the species the better it seems to thrive when breeding upon fish in captivity. Argulus mississippiensis and A. lepidostei breed in large numbers upon the gars used in experiment work at Fairport, Iowa. The present author, assisted by Mr. H. W. Clark, picked over 1,200 specimens of these two species of parasites from three rather small gars at Fairport, September 3, 1920.

\section{ARGULUS PAULENSIS, new species.}

\section{Plate 1, figs. 1-5.}

Host and record of specimens.-Two females and a male of this new species were taken from the outside surface of a fresh-water fish called by the natives "Talrirana" at Itatiba, Sao Paulo, Brazil. Both females contained eggs nearly ready for laying, and the larger one was evidently fully matured. The three have been given Cat. No. 54111, U.S.N.M., and the larger female is made the type of the new species.

Specific characters of the female.-Carapace orbicular, a little wider than long and three-fourths of the entire length, but not covering the bases of the third and fourth legs. Posterior sinus wide and shallow, one-fifth the length of the carapace, its lateral margins widely divergent; posterior lobes broadly rounded. Free thorax narrowing rapidly posteriorly; abdomen elliptical, one-fourth longer than wide; anal sinus wide and about one-quarter the length of the abdomen (28 per cent); anal laminae subbasal, long and narrow.

First antennae long and moderately stout, no hook or spine on the anterior margin; lateral hook as long as the terminal portion and strongly curved. Second antennae short and rather stout. Eyes 
small, placed far forward, well separated, and very weakly pigmented. Sucking disks large, and placed well forward, each one-fifth as wide as the carapace. The ribs which support their free margins are slender, straight, tapering, and about 12 -jointed. The maxillipeds are stout, the basal joint armed with three bluntly truncated laminae on its posterior margin; the ventral surface of the second and third joints is covered with small corrugations which do not quite touch one another. The first and second legs are well covered by the carapace, the third and fourth pairs are entirely visible in dorsal view. The lobes on the basal joints of the fourth pair are narrowconical and about half the length of the second joint. The first two pairs are furnished with large flagella, but there are none on the last two pairs; these are specially prominent on the older female.

Color.-(Preserved material) a plain grayish white, the eggs showing through as a distinct orange-yellow; eyes almost invisible but with a faint wash of reddish-brown.

Total length $6 \mathrm{~mm}$. Carapace $4.50 \mathrm{~mm}$. long, $4.80 \mathrm{~mm}$. wide. Abdomen $1 \mathrm{~mm}$. long, $0.80 \mathrm{~mm}$. wide. The larger female measures $8.50 \mathrm{~mm}$. in total length and the carapace is $7.50 \mathrm{~mm}$. wide.

(paulensis, from Sao Paulo, Brazil.)

Specific characters of the male.-The male is smaller than the female but otherwise quite similar. Carapace wider than long and not reaching the anterior margins of the third legs. Abdomen relatively larger than in the female and nearly as wide as long. Eyes larger, farther forward, and closer together than in the female. Of the supplementary sexual characters the peg on the second joint of the fourth legs is large and long and extends diagonally outward. There is a small protuberance on the posterior margin of the basal joint of the third legs, and a wide flap or lamina on the posterior margin of the second joint. The second legs have a long and narrow flattened projection on the posterior margin of the second joint.

Color.-Similar to that of the female.

Total length $5.50 \mathrm{~mm}$. Carapace $3.85 \mathrm{~mm}$. long, $4 \mathrm{~mm}$. wide. Abdomen $1.08 \mathrm{~mm}$. long, $1 \mathrm{~mm}$. wide.

Remarks.-This is another of the fresh-water argulids of South America, and may be distinguished from Krøyer's salminei as follows:

Krøyer said of his species, "Color a pleasing liver-brown, with a narrow dark margin anteriorly on the upper surface of the carapace and a small dark spot at the base of the incision of the tail (genital segment). The grooves which separate the cephalic from the lateral areas are darker and more yellow in color than the rest of the dorsal integument. Eyes black * * *. In the male the dark border of the carapace and the small black spot at the base of the anal sinus 
are lacking." " $\mathrm{He}$ was describing preserved material from the Copenhagen Museum and hence his statements may safely be compared with those made above for the present species. Here the color is plain white, the only pigment visible is the orange-yellow of the matured eggs, the eyes are not black but very pale reddishbrown. In salminei the carapace is longer than wide; Kroyer gave the proportion as 20 to 19 ; here it is wider than long, as 19 to 18 . In salminei the abdomen of the female is one-eighth of the total length and is wider than long; here the abdomen is one-sixth of the total length and is a fourth longer than wide.

Krøyer's specimen of the male was a little more than a third of the length of the female, its carapace lobes overlapped the abdomen, and both carapace and abdomen were considerably longer than wide. In the present species the male is relatively much larger, its carapace lobes do not reach even the third legs and the carapace is decidedly wider than long while the abdomen has a length and breadth which are about equal. In salminei the sucking disks are each a third of the width of the carapace and so close together that they nearly touch; here they are less than a fifth of the width of the carapace and are well separated. In salmine $i$ the posterior sinus of the carapace is one-fourth of the length of the carapace with nearly parallel sides; here it is much shorter and the sides are widely divergent.

The male described by Thiele ${ }^{5}$ and referred to Kroyer's salminei apparently does not belong to that species. It does, however, correspond almost exactly with the present species and may well belong here.

ANCHISTROTOS OCCIDENTALIS, new species.

Plate 2, figs. 10-18.

Host and record of specimens.--Six females with egg strings were taken from the gills of the orange file fish, Alutera schoep fii at Woods Hole, July 13, 1911, by V. N. Edwards. They become the types of the species and have been given Cat. No. 54138, U.S.N.M.

Specific characters of the female.-Cephalothorax strongly arched dorsally, flattened and reentrant ventrally and much larger than any of the free thorax segments. The latter diminish regularly in size and the fifth segment is distinctly separated from and considerably wider than the genital segment, its greatest width being through the bases of the fifth legs. The genital segment is much wider than long; the abdomen is four-jointed, the joints about the same length but diminishing slightly in width. The anal laminae are small, widely separated, and divergent, each armed with two unequal setae at the tip and several smaller ones on the dorsal surface. The egg

4idrag til Kundskab om Snyltekrebsene, 1863, p. 16.

5 Mittheilungen aus dem Zoologischen Museum zu Berlin, vol. 2, pt. 4, p. 26. 
strings reach to about the center of the long anal setae, eggs in seven or eight rows, about 15 in each row.

First antennae cylindrical, slightly widened and flattened at the base, indistinctly six-jointed, and armed with rather small setae. Second antennae small, the terminal joint tipped with two long, curved claws, with three setae on the inner margin and a corrugated area similar to that in Bomolochus on the outer margin. Maxillipeds with a stout and well developed basal joint and a slender terminal claw, the latter bent into the shape of a sickle. First swimming legs with each ramus composed of a single joint and armed with broad and flattened setae; second, third, and fourth legs with toothed spines on their outer margins, five on the second and third legs and three on the fourth legs. In addition to the teeth along its outer margin each spine has a terminal filament attached to its inner margin near the tip (fig. 18).

Color--(Preserved material) a uniform light yellowish-brown.

Total length, including anal setae, $2 \mathrm{~mm}$. Cephalothorax $0.50 \mathrm{~mm}$. long, and the same width. Free thorax $0.80 \mathrm{~mm}$. long; second segment $0.35 \mathrm{~mm}$. wide.

(occidentalis, western, American, in allusion to the fact that all the preceding species of the genus have been obtained from the Mediterranean.)

Remarks.-This genus was established by Brian in 1906 to include some tiny parasites found upon fish in the Bay of Naples. Two other species, also from the Mediterranean, were transferred to this genus by the present author in 1911. The species here described is the first to be found outside of the Mediterranean and this fact has been emphasized in the specific name.

\section{PARAPANDARUS, new genus.}

Generic characters of female.-Body elongate-obovate; cephalothorax narrowed anteriorly, cephalic area clearly differentiated, no posterior lobes. Second, third, and fourth thoracic segments each with a pair of dorso-lateral plates; fourth legs visible dorsally on either side of the genital segment behind the third pair of plates. Genital segment not hardened on dorsal surface; sixth segment in the form of a rounded lamina fitting into the posterior sinus of the genital segment as in Pandarus. Abdomen one-jointed, with modified anal lamina. Egg strings attached to genital segment between sixth segment lamina and abdomen. First three pairs of legs with two-jointed rami; rami of fourth pair one-jointed. Second antennae much enlarged, prehensile; maxilliped with terminal claw and not a pad.

Generic characters of male.-Carapace broad; posterior lobes straight and bluntly rounded; no secondary lobes; lateral grooves 
similar to those in Pandarus male; frontal plates prominent, separated by a deep central sinus. Free segments without dorsal plates, all of the same width which is equal to that of the genital segment. Second segment with a pair of postero-lateral lobes, extending diagonally outward and backward; fourth segment with a lateral knob on either side, nearer the anterior margin. Genital segment with knob-like processes at anterior corners and wide rounded lobes at the posterior corners. Abdomen two-jointed, joints equal. Swimming legs all biramose, rami two-jointed. Maxillipeds with stout terminal claw, shutting against two corrugated knobs on basal joint.

\section{PARAPANDARUS NODOSUS, new species.}

Plate 2, figs. 19-24; plate 3.

Host and record of specimens.-Twenty females and ten males of this new genus and species were taken from the gills of a large hammerhead shark, Sphyrna zygaena, at Woods Hole, July 5, 1911. All were full grown and the females each bore egg strings. Both sexes were securely fastened to the gill arches by their powerful second antennae and maxillipeds. This will be noted as one important difference between the present genus and Pandarus, the latter being always an external parasite on the fins or skin.

A single female has been selected as the type of the new species and has been given Cat. No. 54139, U.S.N.M. The remaining specimens become paratypes with Cat. No. 54140, U.S.N.M.

Specific characters of female.-To the generic characters already given the following may be added. The width of the carapace across its posterior margin is to its length as 8 to 5 ; the posterior corners are bluntly rounded and point straight outward; the posterior margin is nearly straight and has no trace of teeth, so common in Pandarus. On either lateral margin, a short distance in front of the posterior corner is a notch representing the division between the head and the first thoracic segment. If a line be drawn from this notch diagonally inward and backward to the center of the posterior margin, the triangular corner of the carapace outside of and behind the line will represent one dorsal plate of the first thoracic segment. In specimens which have become swollen by the preservative this first plate is often inclined upward at an angle with the rest of the carapace, and is thus still further differentiated. The dorsal plates of the second, third, and fourth thoracic segments are attached to the dorsal surface of their respective segments diagonally, and project outward and backward in broadly rounded curves. The combined width of the two plates forming each pair is about equal to that of the carapace. The first pair do not quite touch each other on the midline and a triangular portion of the second segment comes to an 
invaginated point between them. "The bases of the other pairs do touch and the plates themselves overlap slightly. Posteriorly the third plates slightly overlap the genital segment. Behind these plates on either side is seen another similar lamina, which appears at first sight like one of another pair of plates, but is really the enlarged basal joint of the fourth swimming leg.

The genital segment is a little longer than wide with rounded corners and a wide sinus at the center of the posterior margin on the dorsal surface. On the ventral surface is the base of the abdomen, on either side of which a stout spine extends backward and is visible in dorsal view behind the genital segment and outside of the sixth segment.

The abdomen is one-jointed and is covered ventrally by a rounded plate, slightly invaginate on its posterior margin and extending considerably beyond the sixth segment lamina in width and length. Near its base this plate bears a pair of modified anal laminae similar to those on Pandarus. There are no adhesion pads anywhere on the ventral surface; the exceptionally developed second antennae are abundantly capable of holding the parasite securely in position. Moreover its mode of attachment is entirely different from that of Pandarus. The latter fastens itself to the flat surface of the fins or skin where an adhesion pad can and does function. The present genus fastens to the gill arch and its body hangs free so that adhesion pads would be of no service. The egg strings are attached to the posterior end of the genital segment between the sixth segment lamina and the abdomen and are from one and a half to two times the length of the whole body.

The first antennae are like those of Pandarus; the second pair are greatly enlarged and are bent into the shape of a sickle. They project in front of the carapace and are visible in dorsal view. The mouth tube is narrow and conical, three times as long as it is wide at the base and sharply pointed. The first maxillae are short and consist of a moderately stout basal joint and a comparatively small terminal claw; they are situated at the base of the mouth tube and point inward toward each other. The second maxillae have a stout basal joint with a projecting knob on its outer margin near the tip, while the terminal claw is bifid for half its length. The basal joint of the maxillipeds is triangular and the stout terminal claw is attached to the outer corner of its distal margin. At the inner corner is a cup-shaped hollow into which the tip of the claw fits when it is closed.

The rami of the first three pairs of swimming legs are two-jointed, those of the fourth pair are one-jointed. The basal joint of the exopod of the first legs is armed with a single spine, while the ter- 
minal joint has a row of seven spines around its margin, but no hairs or setae. The basal joint of the endopod is unarmed, while the terminal joint has a single spine and a fringe of short hairs. The basal joints of the other legs have a fringe of hairs along their outer margin, and the rami are armed with both hairs and spines but no setae.

Color.-(Preserved material) a uniform yellowish white without pigment anywhere. But the specimen were evidently preserved in picric acid so that their present color counts for very little.

Total length $13 \mathrm{~mm}$. Carapace $3.85 \mathrm{~mm}$. long, $6.40 \mathrm{~mm}$. across its posterior margin. Genital segment $4.20 \mathrm{~mm}$. long, $3.60 \mathrm{~mm}$. wide. Egg strings 15 to $20 \mathrm{~mm}$. long and very slender.

(nodosus, covered with knobs, alluding to the sides of the fourth segment and the anterior corners of the genital segment in the male.)

Specific characters of male.-Carapace orbicular, as wide as long; posterior lobes one-third the length of the carapace and broadly rounded; posterior margin straight and unarmed; lateral grooves distinct and S-shaped. First free segment with a lateral lobe on either side extending diagonally backward; second free segment transversely elliptical, one-half wider than long. Third free segment with each lateral margin prolonged into a conical knob, pointing diagonally forward and with a bluntly rounded tip; the segment in front of the knobs is narrowed into a short neck.

The genital segment is oblong, nearly a half longer than wide; the anterior corners are prolonged into knobs similar to those on the sides of the fourth segment, while the posterior corners extend backward in wide, bluntly rounded lobes, which are curved slightly inward. On the sides of the segment.just in front of the posterior lobes the rudimentary fifth legs are visible in ventral view.

The abdomen is two-jointed and shaped somewhat like an hour glass, being narrower across the groove that separates the two joints, and wider across the anterior and posterior ends. The anal laminae are huge affairs, each of them wider and longer than the entire abdomen, overlapping at the center and tipped with four large nonplumose setae.

Of the appendages the second antennae are smaller than those of the female but still larger than the average for these Nogaus forms. The maxillipeds have a triangular basal joint but their attachment is near the center of one of the sides instead of at one of the apices. The terminal claw, instead of shutting down into a pocket, shuts against two corrugated knobs on the basal joint. The swimming legs are armed with stout plumose setae and spines arranged as follows, the setae appearing first; first endopod, $0-0$, $4-0$; first exopod, $0-1,3-4$; second endopod, $1-0$, 8-0; second 
exopod, $0-1,6-3$; third endopod, $1-0,6-0$; third exopod, $0-0$, $5-4$; fourth endopod, $1-0,5-0$; fourth exopod, $1-1,4-4$.

Remarks.-This new genus is closely related to Pandarus as has been indicated in its name. It differs, however, in the size, shape, and arrangement of the dorsal plates on the free thorax, in the greater development of the second antenae, in the entire absence of adhesion pads, and in the relative size of the sixth segment and abdomen in the female. The male differs in the knobs on the lateral margins of the fourth segment and at the anterior corners of the genital segment, and in the great enlargement of the anal laminae. The body, the plates, and the appendages are softer than those of Pandarus and easily become inflated in the preservative.

\section{NEW HOSTS AND NEW LOCALITIES.}

ARGULUS ALOSAE Gould. Four lots of this species were taken from tomcod, Microgadus tomcod, in Bass River, Nova Scotia July 27, 1921. After identification they were returned to the Commissioner of Dominion Fisheries at Ottawa, Canada.

ARGULUS LATICAUDA Smith. Twelve specimens, including both sexes, were taken from the toadfish, Opsanus tau, at Woods Hole August 4, 1908. They have received Cat. No. 54104, U.S.N.M.

ARGULUS PUGETTENSIS Dana. Four females were taken by the Fisheries steamer "Albatross" from the viviparous nerch, Cymatogaster aggregatus, off the coast of California in the summer of 1915, and have received Cat. No. 53496, U.S.N.M. Two lots, including both sexes, were obtained from the walleyed surffish, Hyperprosopon argenteus, on the Pacific coast by J. R. Beck. They have been given Cat. Nos. 53532 and 53533 U.S.N.M. respectively.

ARGULUS STIZOSTETHII Kellicott. Twelve females and two males were taken from the Muscalunge, Esox nobilior, in Squirrel Lake, Vilas County, Wis., July 20, 1907. One female and one male have been deposited in the National Museum with Cat. No. 49797, U.S.N.M.

CALIGUS RAPAX Milne Edwards. A single female was found in the mouth of a striped sea robin, Prinotus striatus by V. N. Edwards at Woods Hole May 14, 1913, and has been given Cat. No. 54105, U.S.N.M.

CALIGUS THYMNI Dana. Two females were taken from the gills of a swordfish, Xyphias gladius, at Woods Hole, July 14, 1911, by Dr. Edwin Linton. They have received Cat. No. 54103, U.S.N.M.

LEPEOPHTHEIRUS EDWARDSI Wilson. Two males were taken from the gills of the goosefish, Lophius piscatorius at Woods Hole, May 25, 1914, by V. N. Edwards, and have been given Cat. No. 54106, U.S.N.M.

LEPEOPHTHEIRUS PARVIVENTRIS Wiison. Two females were taken from a kelpfish, Iridio semicinctus, on the coast of southern California and have received Cat. No. 53492, U.S.N.M. Three females were taken from a sting ray, Urolophus halleri, by Prof. A. B. Ulrey in an aquarium at the marine station of the University of Southern California, at Venice, California, July, 1919, and have received Cat. No. 53553, U.S.N.M.

ALEBION GRACILIS Wilson. A single female was taken from the skin of Milbert's shark, Carcharhinus milberti, at Woods Hole, August 5, 1922, by Dr. H. M. Smith. It has received Cat. No. 54141, U.S.N.M., and is the first specimen of this sepcies to be recorded from this host. 
PANDARUS CRANCHII Leach. A dozen females were taken from the skin of the same Milbert's shark, and have been given Cat. No. 54150, U.S.N.M.

ECHTHROGALEUS COLEOPTRATUS Guérin. A single female was taken in company with the two preceding species, Cat. No. 54149, U.S.N.M.

ERGASILUS CAERULEUS Wilson. Four females were found upon the gills of the common sucker, Catostomus commersoni, at Green Bay, Lake Michigan, by Prof. A. S. Pearse, August 3, 1920. They have received Cat. No. 54146, U.S.N.M. Another lot of twelve females was taken at the same time and place from the gills of the redeye, Ambloplites rupestris, and has Cat. No. 54145, U.S.N.M.

ERGASILUS MANICATUS Wilson. Ten females were taken from the gills of the two-spined stickleback, Gasterosteus bispinosus, at Woods Hole July 20, 1910, by Dr. Edwin Linton; Cat. No. 54107, U.S.N.M.

ERGASILUS VERSICOLOR Wilson. Twelve females were taken from the gills of the red-mouthed buffalo, Ictiobus cyprinella by the present author at Fairport, Iowa, July 20, 1915 ; Cat. No. 53497, U.S.N.M.

ANTHOSOMA CRASSUM (Abildgaard). Four females were taken from the gills of a man-eater shark, Carcharodon carchariae at Woods Hole, June 23, 1910, by V. N. Edwards ; Cat. No. 54110, U.S.N.M.

LERNANTHROPUS BREVOORTIAE R. Rathbun. Two females were taken from the gills of the hickory shad, Pomolobus mediocris, at Woods Hole. August 20, 1910, by Dr. Edwin Linton; Cat. No. 54108, U.S.N.M.

NEMESIS ATLANTICA Wilson. Four females were found on the gills of the dusky shark, Carcharias obscurus, at Woods Hole, July 25, 1910, by Dr. Edwin Linton; Cat. No. 54109, U.S.N.M. A second lot of twelve females were taken from the gills of a thresher shark, Alopias vulpes, at Woods Hole, August 23, 1922, by Dr. H. M. Smith ; Cat. No. 54147, U.S.N.M.

KRøYERIA LINEATA P. J. van Beneden. A single female was found on the gills of a hammerhead shark, Sphyrna zygaena, at Woods Hole, July 5, 1911, by V. N. Edwards; Cat. No. 54142, U.S.N.M. This species has never before been reported outside of the Mediterranean.

LERNAEA CRUCIATA (Le Sueur). A single female was taken by the present author from the flesh of the bluegill, Lepomis pallidus, at Fairport, Iowa, July 15, 1918; Cat. No. 53477, U.S.N.M. Two females were also taken from the flesh of the wide-eared sunfish, Lepomis euryorus at the same time and place; Cat. No. 53479, U.S.N.M. Two females were taken from the flesh of the orange-bellied sunfish, Lepomis miniatus, in Bear Lake, Louisiana, by A. F. Shira, former superintendent of the biological station at Fairport; Cat. No. 53480, U.S.N.M.

IERNAEA VARIABILIS (Wilson). Two females were taken from the flesh of the bullhead, Ameiurus nebulosus, July 21, 1920, at Fairport, Iowa, by the present author; Cat. No. 53470, U.S.N.M.

PENNELLA ORTHAGORISCI Wright. A single female was taken from the flesh of the albacore, Germo alalunga, at Santa Cruz Island, California, September 24, 1919, by O. E. Sette; Cat. No. 54148, U.S.N.M.

CLAVELLA INSOLITA Wilson. Two females were obtained from the gills of Notothenia sima in the Straits of Magellan by the fisheries steamer "Albatross" in the summer of 1908; Cat. No. 53476, U.S.N.M. This species has been known hitherto only from the north temperate Atlantic.

IERNAEENICUS AFFIXUS Wilson. Two females were obtained by V. N. Edwards from the flesh of the common stickleback, Gasterosteus bispinosus, at Woods Hole, July 16, 1910 ; Cat. No. 53474, U.S.N.M. 
IERNAEENICUS LONGIVENTRIS Wilson. Two females were taken from the flesh of the sea drum, Pogonias cromis, at Ocean View Station, Norfolk, Va., October 13, 1922 ; Cat. No. 56551, U.S.N.M.

SALMIINCOLA GIBBER (Wilson). Ten females from the roof of the mouth and tongue of the char, Salvelinus alpina alipes, from Cairn Lake, and twelve females on the same host from Konochickalak Lake, McMillan's Baffin Land Expedition, June 28 and July 7, 1922 ; Cat. No. 56552 and 56553, U.S.N.M.

SALMINCOLA CARPENTERI (Packard). A dozen females were obtained by the fisheries steamer "Albatross" from the gills of the Frazer River salmon, Oncorhynchus nerka, in British Columbia; Cat. No. 53512, U.S.N.M.

ACHTHERES AMBLOPLITIS Kellicott. Twelve females were taken from the gills of the burbot, Lota maculosa, at Sturgeon Bay, Lake Michigan, July 27, 1920, by Prof. A. S. Pearse; Cat. No. 54144, U.S.N.M.

ACHTHERES COREGONI (S. I. Smith). A single female from the gills of the blackfin cisco, Leucichthys nigripinnis, at sturgeon Bay, Lake Michigan, July 26, 1920, by Prof. A. S. Pearse; Cat. No. 54143, U.S.N.M.

ACHTHERES CORPULENTUS Kellicott. Two females from the gills of the cisco, Leucichthys johannae, at the same place and date; Cat. No. 56554, U.S.N.M.

\section{NOTES ON COPEPOD NOMENCLATURE.}

During a study of parasitic copepods extending over 20 years many discrepancies have been observed, which there has been no opportunity to correct. At the very outset of the work it was realized that, while it is possible to separate the group on an ecological basis into free-swimmers, semiparasites, commensals, and parasites, these distinctions largely disappear when the copepods are considered from a morphological or systematic standpoint. Accordingly it was found necessary to include the entire group both in the bibliography and in the record of species and genera. As a result two card catalogues have been gradually accumulated, one bibliographic and the other systematic. By comparing the two with each other and with Scudder's Nomenclator Zoologicus and Sharp's Index Zoologicus it has been possible to separate a group of generic and specific names which have been preoccupied. Another small group are of such doubtful validity that they can not be accepted according to our present knowledge, or must even be discarded. A third group contains a remarkably large number of copepod genera, which were established prior to 1901 , but which do not appear in either of the above lists. And finally there are numerous instances in which mistakes or omissions have been made in the record as it appears in the two lists named above.

\section{PREOCCUPIED GENERIC NAMES.}

In suggesting names to replace those already used an effort has been made to preserve as far as possible the meaning of the original word. Where this has proved to be impractical the name has been radically changed. 


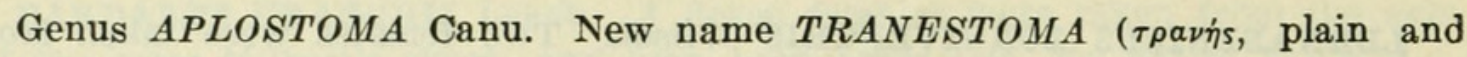
$\sigma \tau \dot{o} \mu a$, mouth).

Aplostoma Canu, Comptes Rendus, vol. 103, 1886, p. 1025.

Type of genus, Aplostoma brevicauda Canu, monotypic.

Aplostoma was used by Moquin-Tandon in 1885 for a genus of mollusks.

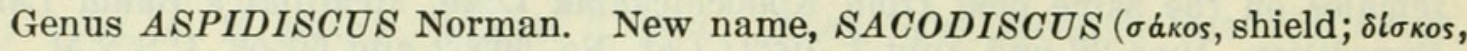
carapace).

Aspidiscus Norman, Report of British Association for Advancement of Science, 1868, p. 298.

Type of genus, Aspidiscus fasciatus Norman, monotypic.

Aspidiscus used for genus of polyps in 1825 by Könnetchtedy. Norman's genus not accepted by Brady in 1880, but restored by Sars in 1904 .

Genus $A X I N E$ Oken. NAOBRANCHIA Hesse (?), 1863.

Axine Oken, Lehrbuch der Natunrgeschichte, 1816, p. 357.

Type of genus, Axine bellones Oken.

Oken's species has never been identified, but from his description was probably identical with Hesse's species. Whether this be true or not, the name Axine was used by Abildgaard in 1795 (1794 according to Sherborn) for a genus of Vermes.

Type of Naobrachia, Naobranchia cygniformis Hesse, monotypic.

Genus BELISARIUS Maupas. PHYLLOGNATHOPUS Mrázek, 1893.

Belisarius Maupas, Comptes Rendus, vol. 115, 1892, p. 135.

Type of genus, Belisarius viguieri Maupas, monotypic.

Scourfield in Journ. Quekett Micros. Club, Nov. 1903, made Mrázek's monotype identical with that of Maupas. But the name Belisarius was used for a genus of arachnids by Simpson in 1879, and hence Mrázek's genus name must be substituted for it. No other author has noted either monotype.

Genus BRYAXIS Sars. New name, COMANTENNA (Comans, hairy; antenna, feeler).

Bryaxis Sars, Crustacea of Norway; Copepoda Calanoida, 1902, p. 35.

Type of genus, Bryaxis brevicornis Sars, monotypic.

Sars explained that this was a manuscript name applied to the genus by Boeck, but Leach had used the same word for a genus of beetles in 1817, and Kugelann also for a genus of Coleoptera in 1794.

Genus CALIGINA P. J. van Beneden. TREBIUS Krøyer (?), 1838.

Caligina Beneden, Mémoires de l'Académie royale de Belgịque, vol. 33, 1861, 1. 127 .

Type of genus, Trebius caudatus Krøyer, (1838), monotypic.

Beneden's type species was described but never figured, and from the de. scription must have belonged to Krøyer's genus.

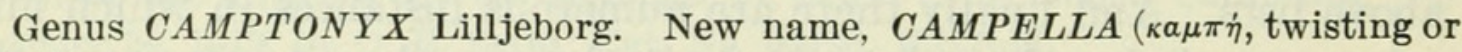
winding).

Camptonyx Lilljeborg Öfversigt af konglige Vetenskaps Akademiens, Förhandlingar, vol. 32,1875 , p. 11.

Type of genus, Camptonyx parentii Lilljeborg, monotypic.

Lilljeborg's genus name had been used in 1858 by Bensdorf for a genus of univalve mollusks and also by Heller for a very different genus of crustacea.

Genus CEYLONIA Thompson and Scott. New name, CEYLONIELLA.

Ceylonia Thompson and Scott, Ceylon Pearl Oyster Fisheries, Report, 1903, pt. 1, p. 265. 
Type of genus, Ceylonia aculeata Thompson and Scott, monotypic.

Ceylonia was used by Buckton for a genus of insects in 1891.

Genus CONOSTOMA Thomson. New name, THOOSTOMA (ooós, pointed; $\sigma \tau \delta \mu a$, mouth.)

Conostoma Thomson, Transactions of the New Zealand Institute, vol. 15, 1883 , p. 93.

Type of genus, Conostoma ellipticum, monotypic.

Conostoma was used by Hodges in 1842 for a genus of birds.

Genus CORINA Giesbrecht. New name, VETTORIA ("Vettor Pisani," name of vessel).

Corina Giesbrecht, Atti Accademia Lincei, Roma, ser. 4, vol. 7, 1891, p. 479.

Type of genus, Corina granulosa Giesbrecht, monotypic.

Corina was used in 1887 by Westerlund for a genus of mollusks.

Genus CRYPSIDOMUS Levinsen. New name, APHANODOMUS (áyavìs, hidden).

Crypsidomus Levinsen, Videnskabelige Meddelelser fra naturhistoriske Forening i Kjøbenhavn, 1877 , p. 375.

Type of genus, Crypsidomus terebellae, monotypic.

Crypsidomus was used by Günther for a genus of reptiles in 1864 .

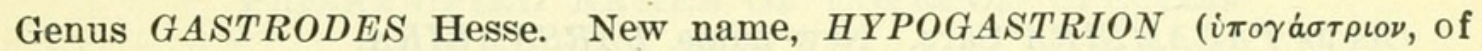
the belly).

Gastrodes Hesse, Annales des sciences naturelles, ser. 5, vol. 6, 1866, p. 73.

Type of genus, Gastrodes viridis Hesse, monotypic.

Gastrodes was used by Westwood for a genus of Hemiptera in 1839, and also in 1888 by Korotnev for a genus of Coelenterates.

Genus HYPNODES Hesse. New name, HYPNOTICUS (i் $\nu \omega \tau \iota \kappa o ́ s$, sleepy.) Hypnodes Hesse, Annales des sciences naturalles, ser. 5, vol. 4, 1865, p. 247. Type of genus, Hypnodes flavus Hesse, monotypic.

Hypnodes was used by Reichenbach for a genus of birds in 1852 .

Genus IDYA Philippi. TISBE Lilljeborg, 1853.

Idya Philippi, Archiv. für Naturgeschichte, vol. 9, 1843, p. 58.

Type of genus, Tisbe furcata (Baird), first species.

Idya was used by Fréminville for a genus of Acalephs in 1809, and Sars proposed to change the name to Idyaea in 1910. But he made Lilljeborg's genus a synonym of Idya, and if this be true Lilljeborg's name must be used and not the modification suggested by Sars.

Genus JURINIA Claus. New name, LOURINIA.

Jurinia Claus, Die Copepoden-Fauna von Nizza, Marburg, 1866, p. 24.

Type of genus, Jurinia armata Claus, monotypic.

Claus named this genus in honor of Prof. Louis Jurine, but the name Jurinia had been used by Desvalles for a genus of Diptera in 1830, and hence Jurine's first name is here substituted.

Genus LEPTOTRACHELUS Brian. New name, AREOTRACHELUS (asaı́s, slender).

Silvestria Brian, Atti della societa Ligustica, vol. 13, 1902, p. 245.

Leptotrachelus Brian, Zoologischer Anzeiger, vol. 26, 1903, p. 547.

Type of genus, Leptotrachelus truchae Brian, monotypic. 
Brian first gave his new genus the name Silvestria, but this had been used for a genus of myriapods in 1895 . He then changed the name to Leptotrachelus, but this was more unfortunate, since it had been used twice, for a genus of beetles in 1829 by Latreille and for a genus of fossil fish in 1863 by Marck.

Genus LEUCKARTIA Claus. New name, RUDOLFIA.

Leuckartia Claus, Die frei-lebenden Copepoden, Leipzig, 1863, p. 182.

Type of genus, Leuckartia flavicornis Claus, monotypic.

Leuckartia was used by Agassiz for a genus of coelenterates in 1862, and hence Leuckart's first name is here substituted.

Genus MONOPS Lubbock. New name, MONACHOPS (rovaxós, single; ó $\psi s$, eye).

Monops Lubbock, Annals and Magazine of Natural History, ser. 2, vol. 12, 1853, p. 122.

Type of genus, Monops grandis Lubbock, monotypic.

Monops was used for a genus of higher crustacea in 1820 by Billberg.

Genus NARCODES Hesse. New name, NARCODINA.

Narcodes Hesse, Annales des sciences naturelles, ser. 5, vol. 4, 1865, p. 236. Type of genus, Narcodes macrostoma Hesse, monotypic.

Narcodes had been used by Agassiz for a fish genus in 1829 and by King for a genus of beetles in 1863 .

Genus PARAMEIRA Sars. New name, SARSAMEIRA.

Parameira Sars, Crustacea of Norway, Copepoda Harpacticoida, vol. 5, 1907, p. 221.

Type of genus, Parameira parva Sars, first species.

Parameira was used by Seidlitz for a beetle genus in 1868 .

Genus PSAMATHE Philippi. SCUTELLIDIUM Claus (1866).

Psamathe Philippi, Wiegmann's Archiv für Naturgeschichte, vol. 6, 1840, p. 189.

Type of genus, Psamathe longicauda Philippi, monotypic.

Psamathe was used by Rafinesque in 1814 for a genus of decapod crustacea, Psamatha was given by Schuckard to a genus of Hymenoptera in 1837, and Psammathe was proposed for a genus of Vermes in 1836. Most authors are agreed that Psamathe longicauda, Philippi's type species is identical with Scutellidium tisboides, the type of Claus's genus. Hence Philippi's specific name must be retained.

Genus SETELLA Dana. New name, DWIGHTIA (James Dwight Dana). Setella Dana, U. S. Exploring Expedition under Wilkes, Crustacea, 1852, p. 1198.

Type of genus, Setella gracilis Dana, first species.

Setella was used by Schrank for a genus of Lepidoptera in 1802.

Genus THAUMATOPSYLLUS Sars. New name THESPESIOPSYLLUS ( $\theta \epsilon \sigma \pi \dot{\epsilon} s \iota s$, wonderful).

Thaumatopsyllus Sars, Archiv for Mathematik og Naturvidenskab, vol. 33, 1913, p. 4.

Type of genus, Thaumatopsylhis paradoxus Sars, monotypic.

In 1894 T. Scott published the name Thaumatopsyllus as a "manuscript synonym" of the genus Aegisthus. This publication of the name as a synonym of another genus prohibits its use by Sars. 


\section{COPEPOD GENERA OF QUESTIONABLE VALIDITY.}

Genus CRYPTOPODUS Hesse, Annales des sciences naturelles, ser. 5, vol. 4, 1865 , p. 23.

Type of genus, Cryptopodus flavus Hesse, monotypic.

From Hesse's figures and text it is impossible to recognize this genus.

Genus PEGESIMALLUS Krøyer, Naturhistorisk Tidsskrift, ser. 3, vol. 2, 1863 , p. 332.

Type of genus, Pegesimallus spiralis Krøyer, monotypic.

In 1869 Steenstrup claimed that Krøyer's specimen was not a copepod but an agalmid colony and recent examination of the type specimen has proved this claim to be true.

Genus UNDINA Dana, U. S. Exploring Expedition under Wilkes, Crustacea, 1852, p. 1092.

Type of genus, Undina vulgaris Dana, first species.

Giesbrecht in 1892 referred Dana's type species to the genus Calanus, and distributed the other species among three additional genera. There may be a question whether Dana's genus entirely disappears, but the name he chose for it was used by Gould for a genus of birds in 1836, by Munsterberg for a fish genus in 1842, and by Gistel for another fish genus in 1848.

\section{PREOCCUPIED NAMES OF COPEPOD SPECIES.}

\section{CYCLOPS CLAUSII Heller. New name, CYCLOPS TERES.}

In the Transactions of the Linnaean Society, vol. 24, 1863, p. 200, Lubbock described a new species, Cyclops clausii, which Sars afterward made a synonym of Cyclops strenuus. Heller in Bericht uber die Medizin und Naturwissenschaft, Innsbruck, vol. 1,1871 , p. 73 , described a new species to which he gave the same name. As the species are distinct Heller's specific name must be changed.

THALESTRIS ROBUSTA Brady. New name, THALESTRIS VALIDA.

In his “Die Frei-lebenden Copepoden," Leipzig, 1863, p. 201, Claus described a new species found in the Mediterranean, Thalestris robusta. Brady in the Transactions of the Natural History Society of Northumberland and Durham, new series, vol. 1,1905 , p. 218 , also described a new species to which he gave the same name. These species are distinct and the specific name given by Brady is changed as above.

\section{NAMES OF COPEPOD GENERA OMITTED FROM THE NOMENCLATOR} AND THE INDEX.

Agenor.-Risso, Histoire naturelle, Paris, 1826, p. 138. Synonym of Argulus. Agnathaner.-Canu, Travaux du Laboratoire de Zoologie maratime de Wimereux, vol. 6,1892 , p. 210 . A valid genus.

Amymone.-Claus, Beiträge zur Kenntniss der Entomostraken, Part I, Marburg, 1860 , p. 11 . A synonym of Tegastes.

Anopherusa.-Templeton, Transactions of Entomological Society, London, vol. 1, 1836, p. 187. A valid genus.

Antheacheres.-M. Sars, Forhandlingar ved de Skandinaviske Naturforskeres, Christiania, 1856 (1857), p. 175. A valid genus.

Arnaeus.-Krøyer, Naturhistorisk Tidsskrift, ser. 3, vol. 2, 1863, p. 157. A synonym of Elytrophora.

Attheyella.-Brady, Monograph of Free and Semiparasitic Copepods, vol. 2, 1880 , p. 58 . A valid genus. 
Belisarius.-Maupas, Comptes Rendus, vol. 115, 1892, p. 135 . A synonym of Phyllognathopus.

Bonnierilla.-Canu, Bulletin scientifique de la France et de la Belgique, ser.

4, vol. 2, 1891, p. 467. Suggested in place of Kerchner's Paryphes.

Caligera.-P. J. van Beneden, Bulletin de l'Academie royale de Belgique, ser.

3, vol. 24, 1892, p. 258. A synonym of Alebion.

Caligidium.-Claus, Arbeiten des Zoologische Institute, vol. 8, 1889, p. 362.

A synonym of Cancerilla.

Calina.-P. J. van Beneden, Bulletin de l'Academie royale de Belgique, ser. 3, vol. 24, 1892, p. 249 . A valid genus.

Cancerilla.-Dalyell, "The Powers of the Creator," London, 1851, vol. 2, p. 223. A valid genus.

Cauloxenus.-Cope, American Naturalist, vol. 6, 1872, p. 420 . A valid genus.

Chelonidium.-Claus, Zeitschrift für wissenschaftliche Zoologie, vol. 25, 1875 , p. 341. Suggested as a substitute for Chelonidiformis.

Collocheres.-Canu, Travaux du Laboratoire de Zoologie maratime de Wimereux, vol. 6,1892 , p. 200 . A valid genus.

Corynuropsis.-T. Scott, Transactions of the Linnean Society of London, vol. 6 , pt. 1,1894 , p. 64 . Claimed by Scott as a manuscript name under date of 1892, and a synonym of Mormonilla.

Cribropontius.-Giesbrecht, Fauna der Station Neapel, vol. 25, 1899, p. 107. A valid genus.

Cryptopontius.-Giesbrecht, Fauna der Station Neapel, vol. 25, 1899, p. 108.

A valid genus.

Cybicola.-Bassett-Smith, Annals and Magazine of Natural History, ser. 7, vol. 2,1898, p. 371 . A valid genus.

Cyclopella.-Claus, Anzeiger Akademie der Wissenschaften, Wien, vol. 9, 1893, p. 81. A synonym of Pterinopsyllus.

Cymbasoma.-I. C. Thompson, Journal Linnaean Society, London, vol. 20, 1888, p. 154. A synonym of Thaumaleus.

Daphinia.-Rafinesque, American Monthly Magazine of Critical Review, vol. 2,1817 , p. 42 . A possible synonym of Calanus.

Doris.-Koch, Deutschlands Crustaceen, Regensberg, 1841, Heft. 35. A synonymn of Canthocamptus.

Dystrogus.-Giesbrecht, Fauna der Station Neapel, vol. 25, 1899, p. 110. A valid genus.

Eikocalanus.-Boeck, Tidsskrift for Fisheri, Kopenhagen, vol. 1, 1867, p. 159. Possibly a printer's error, but has never been explained.

Foroculum.-Thompson, Catalogue of Museum of College of Surgeons, London, 1843 , p. 270 . A synonym of Lernaeenicus.

Gastrodelphys.-Graeffe, Bolletino della Società Adriatica di Scienze Naturali in Trieste, vol. 8, 1883, p. 206 . A valid genus.

Goniopelte.-Claus, Zoologischer Anzeiger, vol. 14, 1891, p. 424 . A synonym of Clytemnestra.

Guernella.-Schmeil, Bibliotheka, Zoologica, vol. 21, 1898, p. 185. A new name proposed for Thomson's Guernea, which had been preoccupied.

Haemobaphes.-Steenstrup \& Lütken, Kongelige Danske Videnskabernes Selskabs Skrifter, ser. 5, vol. 5, 1861, p. 405 . A valid genus.

Hemicalanus.-Dana, U. S. Exploring Expedition under Wilkes, vol. 13, Crustacea, 1852 , p. 1103 . A probable synonym of Centropages.

Hemicyclops.-Claus, Anzeiger Akademie der Wissenschaft, Wien, vol. 9, 1893, p. 80. Preoccupied and hence changed to Halicyclops by Norman in 1903.

Hermannella.-Canu, Bulletin scientifique, vol. 23, 1891, p. 467 . A valid genus. 
Heteropsyllus.-T. Scott, Twelfth Annual Report Fishery Board of Scotland, 1894, pt. 3, p. 252. A valid genus.

Ichnograde.-Hesse, Annales des sciences naturelles, series 5, vol. 1, 1864, p. 349. A doubtful synonym of Enteropsis.

Laophontodes.-T. Scott, Twelfth Annual Report Fishery Board of Scotland, 1894, pt. 3, p. 249 . A valid genus.

Leptopsyllus.-T. Scott, Twelfth Annual Report Fishery Board of Scotland, 1894, pt. 3, p. 254. A valid genus.

Lernaeascus.-Claus, Anzeiger Akademie er Wissenschaft, Wien, vol. 25, 1886, p. 231. A valid genus.

Lernaeenicus.-LeSueur, Journal Academy of Natural Sciences, Philadelphia, vol. 3, 1824, p. 289 . A valid genus.

Lestes.-Krøyer, Danmarks Fiske, Kopenhagen, 1845, vol. 2, p. 517. Name preoccupied and so changed by Krøyer to Lesteira in 1863.

Macrocheiron.-Brady, Natural History Transactions of Northumberland and Durham, rol. 4, 1872, p. 434. A valid genus.

Megabrachinus.-Hesse, Annales des sciences naturelles, ser. 5, vol. 15, 1871, p. 2. A genus of questionable validity.

Megasaonyx.-Hesse, Annales des sciences naturelles, ser. 5, vol. 15, 1871. Title of Article no. 2. Spelled Megasanoixus in text. The latter a valid species.

Monstrilla.-Dana, U. S. Exploring Expedition under Wilkes, vol. 13, Crustacea, 1852, p. 1313. A valid genus.

Mychophilus.-Hesse, Annales des sciences naturelles, ser. 5, vol. 4, 1865, p. 232. A valid genus.

Myicola.-Wright, American Naturalist, vol. 19, 1885, p. 118. A valid genus.

Naobranchia.-Hesse, Annales des sciences naturelles, ser. 4, vol. 20, 1863, p. 122. A valid genus.

Neobradya.-T. Scott, Tenth Annual Report Fishery Board of Scotland, 1892, p. 249 . A valid genus.

Neopontius.-T. Scott, Sixteenth Annual Report Fishery Board of Scotland, 1898, p. 271 . A valid genus.

Nereidicola.-Grube, Verhandlungen Schles. Gesellschaft fur vaterlandische Kultur, 1869-1372, p. 30. A synonym of Nereicola.

Oithonella.-Sars, Norwegian North Atlantic Expedition, part 15, Zoology, vol. 6,1886 , p. 79 . A synonym of Oithona.

Oniscus.-Lamatinière, Journal de Physique, vol. 31, 1787, p. 262 . A synonym of Cecrops.

Otrophesia.-Risso, Histoire Naturelle, Paris, vol. 5, 1826, p. 136. A synonym of Anthosoma.

Panaietis.-Stebbing, Willey's Zoological Results, part 5, 1900, p. 666 . A valid genus.

Papulina.-P. J. van Beneden, Bulletin de l'Academie royale de Belgique, ser. 3, vol. 24, 1892, p. 254. A synonym of Lepeophtheirus.

Paramesochra.-T. Scott, Tenth Annual Report Fishery Board of Scotland, 1892, p, 252. A valid genus.

Philorthragoriscus.-Horst, Notes from Leyden Museum, vol. 19, note 14, 1897, p. 137. A valid genus.

Phyllocamptus.-T. Scott, Journal Linnaean Society, London, vol. 27, 1899, p. 118. A valid genus.

Plantipode.-Hesse, Annales des sciences naturelles, ser. 5, vol. 1, 1864, p. 358. In the text (p. 349) the genus was called Ichnograde, but in the explanation of the plates and on the plate itself the word Plantipode was used. 
Platycheiron.-T. Scott, Tenth Annual Report Fishery Board of Scotland, 1892, p. 153 . A synonym of Hemicyclops.

Pontopolites.-T. Scott, Twelfth Annual Report Fishery Board of Scotland, 1894, p. 251. A valid genus.

Pseudotachidius.-T. Scott, Sixteenth Annual Report Fishery Board of Scotland, 1898, p. 267. A valid genus.

Pseudowestwoodia.-T. Scott, Twelfth Annual Report Fishery Board of Scotland, 1894 , p. 257. A synonym of Parawesturoodia.

Pupulina.-P. J. van Beneden, Bulletin de l'Academie royale de Belgique, series 3, vol. 24, 1892, p. 254. A synonym of Lepeophtheirus.

Ratania.-Giesbrecht, Fauna und Flora des Golfes von Neapel, 19th monograph, Copepoda, 1892, p. 83. A valid genus.

Schizoproctus.-Aurivillius, Ur Vega Expeditionen's Vetenskapeliga Iakttagelser, Stockholm, 1885, vol. 4, p. 246. A synonym of Botryllophilus.

Scaphocalanus.-Sars, Norwegian North Atlantic Expedition, Scientific Results, vol. 5, 1900, p. 36. A synonym of Amallophora.

Seridium.-Giesbrecht, Mitteilungen aus der Zoologischer Station zu Neapel, vol. 12,1897 , p. 223 . A valid genus.

Sestropontius.-Giesbrecht, Fauna der Station Neapel, vol. 25, 1899, p. 107. A valid genus.

Sphaerifer.-Richiardi, Atti della Societa Toscana di Scienze Naturali, vol. 2,1876, p. 99 . A valid genus.

Synestius.-Steenstrup and Lütken, Kongelige Danske Videnskabernes Selskabs Skrifter, ser. 5, vol. 5, 1861, p. 364. A valid genus.

Taphrobia.-Cornalia, Atti della Societa Italiana de Scienze Naturali, vol. 18, 1875, p. 197. A synonym of Peroderma.

Temorites.-G. O. Sars, Norwegian North Polar Expedition, Scientific Results, vol. 5, 1900, p. 100 . A valid genus.

Thaumatoessa.-Hesse, Annales des sciences naturelles, ser. 5, vol. 9, 1868, p. 54. Twice preoccupied and hence changed to Thaumatohessia by Giard in 1900 .

Thaumatohessia.-Giard, Bulletin de Societe Entomologique de France, 1900, p. 395. A valid genus.

Thysanote.-Krøyer, Naturhistorisk Tidsskrift, ser. 3, vol. 2, 1863, p. 288 . A valid genus.

Trophonophila.-McIntosh, Scientific Results, Challenger Expedition, vol. 12, 1885, p. 368. A valid genus.

Trypaphylum.-Richiardi, Atti della Societa Toscana, Processi Verbali, vol. 1, 1878, p. XX. A valid genus.

Undinella.-G. O. Sars, Norwegian North Polar Expedition, Scientific Results, vol. 5,1900 , p. 52 . A valid genus.

Undinopsis.-G. O. Sars, Schneider's Report of Invertebrates from the Kvaenangen Fjord, 1884, p. 131 . A valid genus.

\section{CORRECTIONS AND ADDITIONS TO THE LISTS OF THE NOMEN- CLATOR AND INDEX.}

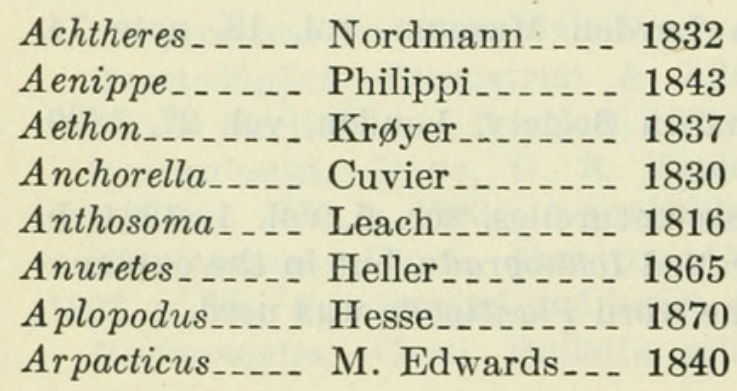

Date supplied.

Date supplied.

Date supplied.

Date supplied.

Date supplied.

Spelled Anuretus in nomenclator.

Spelled Aplopode in nomenclator.

Spelled Arpactes in nomemclator. 


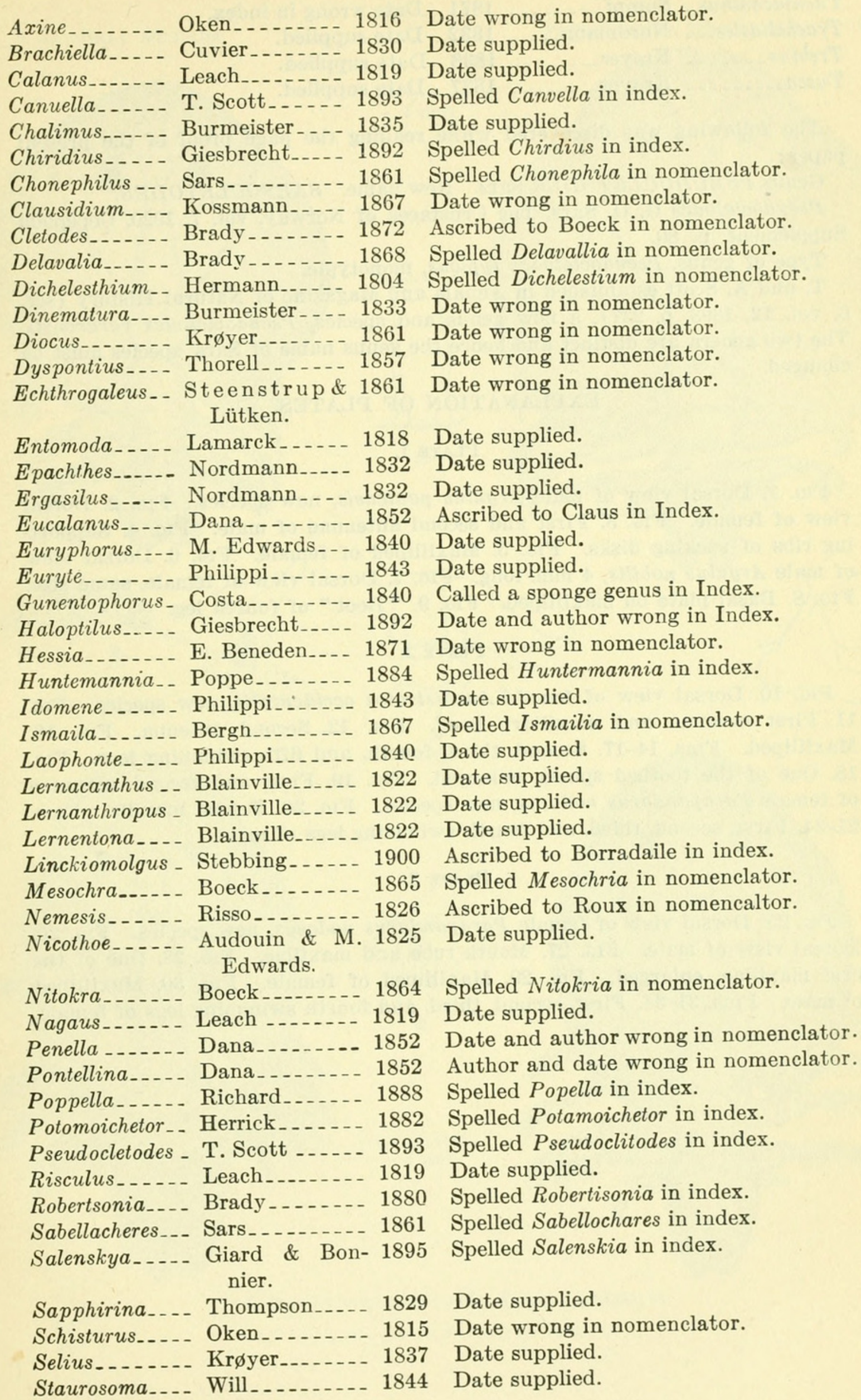




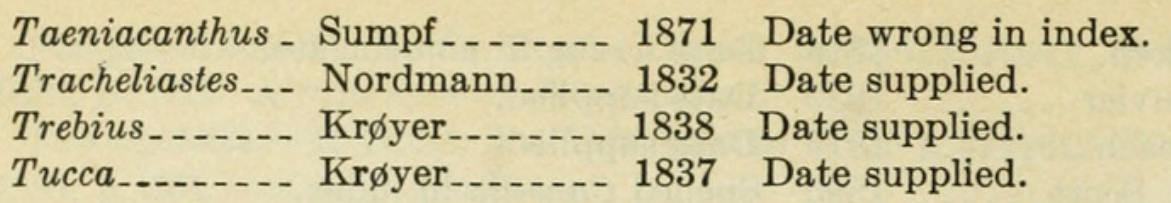

The following was discovered while reading the page proof of the present paper :

Genus PSEUDOCLETODES Sars. New name. SARSOCLETODES.

Pseudocletodes G. O. Sars, The Crustacea of Norway, vol. 7, 1920, Copepoda Supplement, p. 89.

Type of genus, Pseudocletodes typicus, monotypic.

T. and A. Scott established in Annals and Magazine of Natural History (ser. 6, vol. 12, 1893, p. 237), a new genus and species, Pseudocletodes vararensis. The two genera are distinct and hence the genus name of Sars' species must be changed.

\section{EXPLANATION OF PLATES.}

\section{Plate 1.}

Fig. 1. Dorsal view of male Argulus paulensis, new species. Fig. 2. Dorsal view of female. Fig. 3. First and second antennae of male. Fig. 4. Supporting ribs of sucking disks. Fig. 5. Maxilliped of female. Fig. 6. Dorsal view of male Arguhus nobilis, $4 \mathrm{~mm}$. long. Fig. 7. Dorsal view of female, same size. Fig. 8. Basal plate on maxilliped. Fig. 9. "Boot" of fourth leg.

\section{Plate 2.}

Fig. 10. Dorsal view of female Anchistrotos occidentalis, new species. Fig. 11. First antenna and maxillary hook. Fig. 12. Second antenna. Fig. 13. Maxilliped. Figs. 14-17. Second, third, fourth, and fifth swimming legs. Fig. 18. One of the toothed spines, enlarged. Fig. 19. First and second antennae of female Parapandarus nodosus, new species. Fig. 20. Second maxilla. Figs. 21-24. First, second, third, and fourth swimming legs of male.

\section{Plate 3.}

Fig. 25. Dorsal view of female Parapandarus nodosus, new species. Fig. 26. Dorsal view of male. FIg. 27. Mouth tube and maxillae. Fig. 28. One of the first maxillae, enlarged. FIG. 29. Maxilliped of female. FIg. 30. Maxilliped of male. Figs. 31-34. First, second, third, and fourth swimming legs of female. 


\section{$2 \mathrm{BHL}$ Biodiversity Heritage Library}

Wilson, C B. 1924. "New North American parasitic copepods, new host and notes on copepod nomenclature." Proceedings of the United States National Museum 64, 1-22. https://doi.org/10.5479/si.00963801.64-2507.1.

View This Item Online: https://www.biodiversitylibrary.org/item/32410

DOI: https://doi.org/10.5479/si.00963801.64-2507.1

Permalink: https://www.biodiversitylibrary.org/partpdf/1903

\section{Holding Institution}

Smithsonian Libraries

\section{Sponsored by}

Smithsonian

\section{Copyright \& Reuse}

Copyright Status: NOT_IN_COPYRIGHT

Rights: https://www.biodiversitylibrary.org/permissions/

This document was created from content at the Biodiversity Heritage Library, the world's largest open access digital library for biodiversity literature and archives. Visit BHL at https://www.biodiversitylibrary.org. 